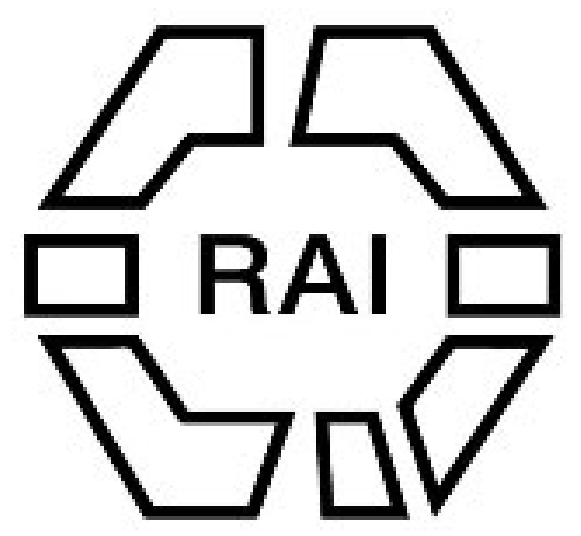

Notes on the Jekris, Sobos and Ijos of the Warri District of the Niger Coast Protectorate Author(s): Reginald K. Granville and Felix N. Roth

Source: The Journal of the Anthropological Institute of Great Britain and Ireland, Vol. 28, No. $1 / 2$ (1899), pp. 104-126

Published by: Royal Anthropological Institute of Great Britain and Ireland

Stable URL: http://www.jstor.org/stable/2842936

Accessed: 11/06/2014 12:39

Your use of the JSTOR archive indicates your acceptance of the Terms \& Conditions of Use, available at http://www.jstor.org/page/info/about/policies/terms.jsp

JSTOR is a not-for-profit service that helps scholars, researchers, and students discover, use, and build upon a wide range of content in a trusted digital archive. We use information technology and tools to increase productivity and facilitate new forms of scholarship. For more information about JSTOR, please contact support@jstor.org. 


\title{
NOTES ON THE JEKRIS, SOBOS AND IJOS OF THE WARII DISTRICT OF THE NIGER COAST PROTECTORATE.
}

\author{
By Reginald K. Granville (late Deputy Sub-Commissioner at Warri, now \\ Assistant Resident at Benin) and Felix N. Ro'nI (late District \\ Medical Officer at Warri). Prepared by H. Lisg RoTII.
}

\author{
[WITH PLATES vi to $\mathrm{x}$.]
}

\section{Introduction.}

IT will probably be a common experience of anthropologists to find that foreign residents are little able to give good accounts of the natives amongst whom they have been thrown. The canses of this inability are manifold. Many such residents are not interested in the natives, and hence do not trouble to use their eyes and ears; others really do not see and hear; while others again -and they form the more numerous class-imagine that what they have seen and heard is too trivial to be put on record, having no notion of the importance of any correct scrap of anthropological news, however small. On more than one occasion, when after a considerable amount of "pumping" I have expressed my satisfaction at having elicited a specially interesting note, my informant has been astonished into saying, "Oh! I did not think you would care to know about such little everyday things." The following notes have nostly been obtained by the process of "pumping."

Both Mr. Granville and my brother had, at my suggestion, commenced taking anthropological notes before their last return to England, and when they visited me, I wrote down the replies they gave to my inquiries, they revising the notes afterwards. While both supplied me with information, more or less equal in quality and quantity, I may mention that the medical and sanitary information is naturally derived from my brother, while the small linguistic portion is solely from Mr. Granville. As the latter is still engaged on the preparation of a Jekri grammar, only a few salient points in the language are produced here. The notes are to a certain extent meagre and fragmentary, but there was no time to do the work more systematically; nevertheless, the little that has been recorded will be found interesting and reliable.

\section{History.}

The Jekris have very fragmentary notions as to their origin, but all the notions point to a westward or Yoruba origin. Some say they are descended from the most casterly of the Yoruba kings' subjects, made up of runaway slaves, 
law-breakers, ete., inter-married with adjoining tribes; they sometimes say jekri means a coward, a man who would not fight, and who was therefore expelled from the tribe. The Yoruba people are, however, mostly horsemen, while the Tekris are a water people who prefer to pardle many miles to walking a few yards. Another statement is that when the Portuguese came to Benin city, one of the leader's sons, a half-caste, was sent down to Warri, or, as the people themselves name the town, Jekri, and there a house was built for him. By means of the juju of the king of Benin (which appears to have always overshadowed Warri), he was declared king of that part of the delta; he brought Yoruba wives with him and was the founder of the Jekri nation. A third statement would seem to be a mixture of the two first, for it says the half-caste found at the delta the Yoruba runaways of whom he constituted himself the chief, and from these Yorubas the Jekris are descended. As, however, Warri Was apparently well established when the Portuguese first visited the country, the story of the half-caste cannot hold good.

At Big Warri, a Jekri will take a stranger "to see what the monks did." There is nothing to be seen except a large open common covered with English (?) grass.

\section{Physique.}

The Jekris may average about 5 feet 7 inches in height; some of them have thiunish lips; they are not well developed about the legs.

The hands of the Jekri women are finely formed and taper, and but for the habit of biting the nails their fingers would look well; as they eat with their fingers, dipping them into the palm oil, etc., for the first inch or two, the fingers get a sort of parchmenty look. The women on Benin river, who have no loads to carry, have well-formed feet with good instep; the feet of the Warri women are nearly as good. The men also have good feet.

The Sobos and Ijos have flatter feet than the Jekris and better calves, the Sobos having the best calves of the three tribes.

The Ijos, while about the same height as the Jekris, are big men physically, with well developed biceps and bull necks; they are better made men than the Jekris, what may be called a good athletic people, and the best watermen of the delta. The women have beautiful figures and very delicately formed feet.

Spurheeledness is not marked, the feet of the natives in that respect resembling those of Europeans very much. All people prefer to paddle a couple of hours to walking a quarter of an hour.

There appear to be no big powerful men, such as are met with elsewhere on the coast.

They can see better in the dark than Europeans are able to do.

\section{Contact with Civilisation.}

The Portuguese appear to have left their mark in the country. There are numerous apparently pure negroes who are orthognathous and have aquiline noses, 
and European features generally, but their hair is woolly. These European features may possibly be partly due to the Europeans who followed the Portugruese, but this is not very likely, as if we take the language into consideration we find numerous words derived from the Portuguese, such words are issangi blood, assetc plate, quierce spoon, gracios thanks, etc.

Strange to say, half-caste babies have straight hair like those of Europeans; it turns woolly afterwards.

$$
\text { Age. }
$$

They have no notion as to their ages, and will fix the date of a birth by some local historical fact such as the time when the first white man came up the creek, etc. They do not appear to live long, and perhaps the average age may be put, down as forty; the men live longer than the women.

\section{Slin Colour.}

The Jekris are generally speaking chocolate-coloured and darker than the sobos, who are rather copper-coloured than black.

\section{Slin Odour.}

The Jekris have a slight smell ; with the Sobos the smell is more pronounced. Practically both Jekris and Ijos have no body smell unless they perspire freely: even then it is very slight and not objectionable, and certainly not so bad as that of an unwashed European. They rub the body with a bitter smelling nut which keeps insects off, and sometimes they use cheap German pomades and then smell very badly.

\section{Childbirth.}

Juju is made before and after childbirth. Among the Jekris only women attend women in labour. A woman in labour sits between the legs of a seated woman behind her, who massages the abdomen downwards and by exerting pressure helps the birth. Miscarriage is not common; but women often require skilled medical help in childbirth and succumb for want of it. As nearly all the natives think nothing of striking a woman, among the Jekris a pregnant woman always wear a small bell suspended from her neck, and as the bell announces her approach, room is made for her and she is not jostled nor struck. Women recover very quickly after childbirth.

Great store is set upon children, and the more children a woman has the more valuable she is; as the natives think a pregnant woman's milk will suffer, and hence also the born or unborn child if she do not leave her husband as soon as she knows of her state, it has become customary for a woman to aroid cohabitation with her husband for nearly three years after pregnancy.

\section{Children.}

Pure negroes when born are pink like young rats; at the end of about three or four months they become black. Teething children are allowed to cry 
themselves quiet as in European hospitals and soon learn that crying is useless. They begin to walk earlier than European children. Rickety children are seldom met with.

Children of all three tribes are carried by being placed astraddle on the mother's hip. The child is then pushed round on to her back (its legs and arms clasping the woman's sides as much as possible), and in so doing the woman bends forward, pulls her upper cloth over the child's body, leaving the head free, generally lolling to one side, and ties the ends of the cloth high over her breasts ; she then resumes her upright position and goes about her duties. A little girl carries a child on her hips.

Excepting in the case of twins every care is taken of children. Mothers rub their babies with their cheeks or mouths but do not kiss them; they lay the babies on their backs on the ground and lying down beside them dangle articles before them and fondle them as in Europe.

Children practically do as they like.

Twins are killed and their mothers turned out of the town and left to die in the bush. The natives say a woman must have been unfaithful to her husband or must have done something very bad to have twins. In the eyes of natives it is quite unnatural to have twins.

The children of a chief by a female slave are free born; the children of a female chief by a male slave are slave born. The children hy a free man of a free woman in pawn are slaves until she has redeemed them by a special payment, whereupon they become free.

The son-in-law gives his father-in-law a "dash" (i.e., present) on the birth of the first child.

\section{Marricuge (Jekri).}

The sexes fall in love with one another just as Europeans do, and there is the same intrigue, squeezing and cuddling and loving embraces, but there is no kissing. Free girls are not given in marriage until arrived at the age of nominal puberty, 2.e., when the pubic hair begins to grow. Marriage consists in payment of a varied amount of cloth, gin, coral, etc., to the parents or brothers, sisters, or other. guardian of the girl. Juju is made at the same time. A girl child can be kept for a man to be his wife when grown up; juju is made to keep her virtuous, but as a rule women are not chaste until married. Slave wives are bought. Most men have more than one wife, whilst chiefs have many wives, the last of whom is generally the favourite; the old wives act as servants.

A chief has as many wives as he can afford to buy. It is sairl no chief tonches his women slaves.

When women are periodically poorly they are not allowed to sleep in the same house as their husbands, neither may they pass the fetish house at the entry to the village, but must enter by a liye-path.

Free born women must not smoke, eat nor drink in the presence of their husbands: slave women ean do so. 


\section{Burial.}

Jekris in mourning for a chief clance at intervals for a period of three to six months after the burial, the period extending according to the rank (power and riches) of the deceased. Towards the end of the mourning there is a biggish dance, then the women shave their heads and the mourning is over. Practically all relations, except the older men who don't bother to do so, shave their heads, and all equally dislike doing it. The dancing consists in making shufflings forward with the feet, a sort of slow polka step one foot at a time; sometimes they stamp with their feet and wriggle their backs and stomachs; they wear a kerchief round the stomach outside their other clothes.

Granville once witnessed a portion of a burial service at Egperiana. Thousands had assembled, but before his arrival the body had been buried already under a house. The daughters of the deceased chief, in rows of four each, danced up and down the compound clapping hands-one, two, three times, emphasis on the first; there was a band consisting of the usual drums, elephant tusk horns (which produced a tooting noise), a pressure drum and bells. The mass of the people looked on and talked. Every now and then an old man, probably a brother of the deceased, threw himself on to the ground on his knees with his legs thrown out sideways and dragged himself up to the burial spot, making flexions and gesticulations as though imitating a Mahommedan at prayers. The daughters and band sang in praise of the deceased.

\section{Character (Jekri).}

The .Jekris could not understand why Felix Roth collected butterflies or flowers, and thought him foolish for so loing, but when it was explained to them that these served as patterns for the printed cottons they began to see some reason in the white man's doings! On seeing roads marle, a Jekri remarked "that he proper place for walk," and on being asked why they did not make proper paths, he replied: "Jekri he fool too much, not got them sense for do that thing, he be lazy man!" They acknowledge that the advent of the white man has been ronducive to their good.

They cannot read a picture until they have been taught to distinguish the figures, ete., and this takes them a long time to do; the diminutive size of the figures would seem to trouble their comprehension at first, for they say, "he small too much." One wife of the King of Benin, brought down to Warri, understood pictures, and clelighted to look in them for children-she had none. Women pick up picture-reading quicker than the men. They soon learn how to use a knife and fork. Many Jekris are now able to walk up and downstairs, but Sobos and Ijos are still very clumsy at this. In going up they will take, say, one step while trying to take two, then when they have got up two or three they look round to sce how it is they have gnt so high; then they take or miss a step or two and lark their shins and look round again. Coming down is much worse, and but for 
the rails many would come to grief, as they have no notion of judging the distance to the next lower step. 'They put one foot forward but not downward, neither' do they bend the standing leg, hence they paw the air and swing round towards the rail in a most awkward manner.

When fighting they claw each other and strike with the flat of the hamd. Hence, when struck with a fist in the face the first time they do not immediately grasp the fact that the opponent has given the blow, but look round to see where it has come from.

If a European argue with them they immediately think he is angry. When quarrelling the men have a trick of suddenly rushing for their opponents' feet, catching them and tripping them rp, and thus laying them on the ground.

The first time Felix Roth entered a Sobo village he shot a bird, for which the chief wanted to fine him. He declined to pay, but threw some threcpenny bits in the air for which the chief scrambled with his people. They kicked each other's shins and got bruised, and then wanted the white man to give them a present to make good the damages they sustained.

The Jekris are most persistent beggars; and a chief will log for cverything he sees and even demean himself to asking for an old shirt, although he may have plenty of good ones at home. A native begging for medicine was told he must pay for it the same as he did for anything else. To this he replied: "Mr. Dotty (i.e., Doctor) you be fine too much" (meaning you know too much); he then put his head on one side, clasped his hands flat together as if in prayer, and begged worse than before until threatened to be kicked out, whereupon he jumped outside, off the verandah, laughed immoderately, threw his arms about, held his sides, lifted his legs in an exaggerated imitation of walking, bent his back and indulged in contortions generally, exclaiming in the most good-humoured way possible, "Mr. Dotty, you vex too much."

They are extremely good natured, but very grasping, and although they are given to immoderate laughter they are not emotional and do not clisplay their feelings. They have a natural politeness which is very striking, and a consideration in delicate matters which is not often met with elsewhere. They cannot be called intelligent, but they are mentally superior to the Sobos and Ijos.

The Jekris have great respect for their chiefs, fathers, and old age generally: in fact public opinion is very strong on these points.

The women of all the tribes are modest, the Jekri women prarticularly so. The wife of the King of Benin washed in the river in front of the consulate at Warri until shown the bath room, with which she evinced the liveliest satisfaction; her apparent indifference previously was due to the eourt etiquette at Benin, where every one appearing before the king had to do so in a state of nudity.

Women when they quarrel accuse each other of immorality, although after marriage they are as true to their husbands or masters as Europeans.

If they do not understand anything they quickly give up thinking aboul it.

The chiefs allow their slivess to steal, and then talke the proceeds of the theft. 
All the people seem to be great thieves, although native women when living with white men never steal nor allow their relations to do so. The thefts of the natives appear to be the outcome of the same mental weakness shown in their cxcessive laughter-they are unable to keep their hands off anything, whether of value to them or not, so that the thieving appears more to take the form of kleptomania on a large scale.

$$
J \text { 'uju. }
$$

The Jekris maintain that with their juju they can find anything you lide. When they fail they say they can, however, tell, in case one's relations at home are ill, whether they will die or not. Repeated failures, nevertheless, do not convince them of the worthlessness of their juju.

Juju-houses in the middle of the compounds have one side quite open and contain all sorts of things, such as clay and wooden figures, broken gin bottles, cowries, beads, wooden plates, palm oil, kernels, bones and skulls of monkeys, dogs, cats and birds, plants, etc. These things are arranged on raised platforms or steps; many of the articles hang from the walls, but everything is whitewashed. Of the many juju-houses seen, none contained anything which could be considered valuable.

The jujus of all three tribes are met with everywhere, in the villages, rivers, bush and bush paths. Apparently the Jekris are greater believers in juju than either the Sobos or Ijos. On the river, as one nears the village, one observes little palm-leaf roofed houses, supported on four, six or eight poles, placed on the banks or in shallow water. These houses contain, hanging in the centre, a piece of white baft or cloth, white being juju for these as well as for the Bini people. On the ground there are broken plates, empty bottles, canoe models, etc. Figures are found in the Sobo, Ijo, and Bini houses, but not in the Jekri houses; the figures are of clay or wood, with the organs of generation always excessively developed. Juju is performed before commencing any business such as housebuilding, fishing, fighting, marriage, childbirth, boat-building, or incleed any undertaking whatever. What they do or what they say we do not know, but some gin is poured over the articles in the bouse whilst the rest is drunk hy those making the juju.

On the bush paths at the entrance to a town there are generally juju-housus,

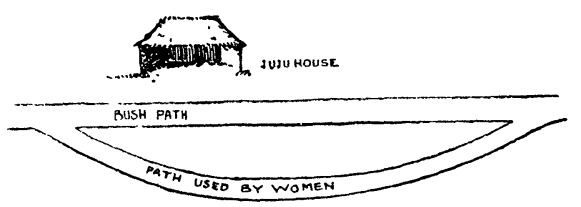
built like the divelling-houses with clay walls, some of the Jekri and Sobo juju-houses being very large. These houses are not actually on the main path to the village but on a side path, and as women, when periodically poorly, are not allowed to pass a juju-house, there is a detour path as shown in annexed sketch.

The placing of a cantoe in a juju-house on the river side, at allove referred to, 
means that if any spirit of a clisease come that way it should go back in the calloc.

Every year all three tribes make juju for the town-to pieserve its health, to prevent death and war, to maintain friendly relations with the neighbouring' villages, to keep on good terms with the consuls, to bring good generally to the inllabitants. The people dance and scream and play and drink gin, some of the latter they sprinkle about the place (figures, walls, etc.).

When men and women have made juju they sometimes paint themselves quite white and leave the paint on until it wears itself off, which it will do in five wr six days. As they do not wash in the meantime they get pretty "lighl." Other's put simply a white mark on their faces, such as a lab of white on the forchead, or on both cheeks, or white rings are marked round the eyes, the object being to let their friends know they have been making juju.

When natives on their way to market pass a juju-house, they speak to it (? the spirit) in quite a friendly way, and promise it something on their return if they shall have traded well. On their return they throw down a banana, or plantain, or some nuts or some small thing they have purchasecl.

Jujus also safeguard property. When a man has been collecting, say sticks or nuts, and is obliged to leave them, he gets a stick, splits it at one end, fixing the other upright in the ground near his belongings; into the cleft of the stick he places a doubled up leaf. Anyone who removes an article thus protected will surely die.

The Ijos have a sort of annual water juju. Hundreds of canoes paddle after two or four men swimming in the water. These men have frames fixed on to their shoulders, 2 feet high and about 3 feet wide, like the roof of a house; the frames are

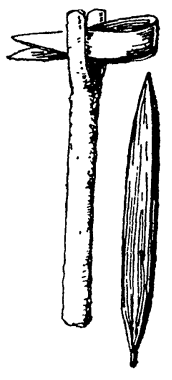
covered with all sorts of coloured cloths. The men sink and emerge slowly, which is a source of great fun to the paddlers.

For several years Felix Roth did not suffer from fever as dicl the other Europeans. This led many individuals of all three tribes to conclude that he posscssed some special medicine, which they pestered him to sell them. When, on his return from the Benin Punitive Expedition, he suffered severely, he maintained the reputation of the medicine by stating he had run out of it and hence had got ill-and the natives believed him! He liad at one time a dogr which he had laught to sit up and give its paw to the natives. This procedure was very uncanny to them, but they thought the dog would make a good fetish and tried to buy it.

The influence of juju cannot be better exemplified than in the belief the natives had in that of the late King of Benin. The Jekris said to the last the British would never take the city because the ling's fetish was too great, and that the ling could not possibly he caught as he would tum himself into a loorse, logr, or bird, ete., and so esseape. When they heard the king hinl been cilphered they 
said: "White man be god man, we no savey them white man; white man pass all other man, palaver set" (i.c., it is no use arguing any more). The Sobos declined to believe in the capture until they were shown the captive king at Warri. They shook their heads and said nothing-it was all beyond them. Both Jekris and Sobos now acknowledge that the king's juju is finished, but go on believing in thir own as heretofore.

If during illness a European doctor requests that for the sake of warmth the patient be covered with a clotl, his request will not be complied with, because in case the patient die the cloth would become juju and could not be used any more.

Their name for God appears to be Oreshé. Their religion seems to consist of "making their fathers." The chief's dead father has always a house in which gin, tobacco, clothes, etc., are continually kept for his use.

The following may possibly be a case of "Long Juju," i.e., a central juju which has greater power than the local surrounding jujus from whom there is appeal :-

About ten days from Warri, there is said to be a big round hole full of water and surrounded by high banks; it is full of alligators and water-snakes, and has been in use for ages as a means of ordeal. Supposing two men have accused each other of doing wrong things, to settle the statenents, they pay some money to the juju-men and are taken to this hole, put into a canoe and upset. If one of the two get ashore alive, he is supposed to be honest; if both succumb, both are lishonest; if both get out alive, both are honest. All three tribes are said to use this ordeal. Granville heard of what appears to be another version of this juju. At Ugélé, where the Sobo king lives, there is a small strip of water 4 yards wide. The accused tries to swim over, and if he is a liar and no true man, he drowns, the water opening up and swallowing him. If, on the other hand, the accused is a "collection of virtues," the devil (consisting of crocoliles, snakes and alligators, the latter with diamonds (? glass) in their heads which shine at night) takes him to the bottom of the water and ties strips of cowries round his wrists and ankles, and bells round his body, arms, legs, etc., telling him he can sell these things in three months' time for chop (food), and then the man comes up. Granville has seen men and women coming from Ugélé one mass of leads.

The sasswood ordeals are as follows. When two men dispute they go to some silsswood man, who rubs the sasswood on the lobes of their respective ears. He then takes a pin and tries to pierce the lobe; if it won't go through the lobe of the man accused, the accusation is false; if it go through, the accusation is true. This is a Jekri and sobo ordeal; the pin is generally the sharpened rib of an umbrella. 'The following is a Jekri ordeal. The bark is stripped off the sasswood tree and made into a mash. Both parties to the dispute (generally about some statement or misstatement) kneel down in front of the tree and eat the mashed up bark, first the accused, then the accuser. When the eating is finished, the two men return to the town and walk about in the largest open space available. They both take an egg in each hand, the eggrs having been previously rubbed in sasswood, and are the 
juju part of the ceremony. The man who has made the misstatement dies while the one wrongfully accused spews up the sasswood.

Food.

The food of the three tribes is very varied, viz., cassava, yams, papau, ground nuts, pineapples, kananas and plantains, palm oil, palm kernels, Indian corm, okra, cocoanuts, oranges, cattle, goats, sheep, dogs, cats, fowls and eggs, wild fowl, bush deer, dried fish and shrimps, land and sea crabs. But the staple food is cassava. The cassava is scraped until the white portion shows; this portion is then scraped on a scraper or knife and made into a pulp from which the juice is well squeezed. This pulp is put into a clay or iron pot, water added, and stirred up until it forms an opalescent mass called $f u f u$. The Jekri then takes a handful, makes it up into a round ball about the size of a small man's fist, dips it into palm oil and swallows it. The Sobos and Ijos after squeezing the pulp bake it dry in pots and put it in the sun until it looks like a lot of crumbs, when it is very hard and brittle. It is then eaten by handfuls with a lot of dried fish or shrimps. The Jekris grow most of the cassava and sell it to the other tribes.

The Jekris preserve cassava dry in leaves. The natives are very fond of starch, and Europeans suffer much theft on this account.

Yams, on account of their comparatively high price, are only eaten by the richer people. Yams are considered poisonous when freshly dug up, and are therefore stocked for future use, just as we do wine in bottles. In both the Jekri and Bini country is this done. The racks are 5 or 6 feet high, of any length, and made of wood lashed

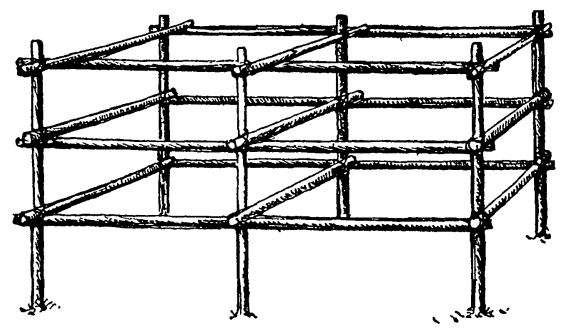
together with $t \bar{\imath}-t \bar{\imath}$. The yams are placed in the pigeon holes so formed, and being preserved from contact with one another, dry well.

Except fish and shrimps, which are smoked, all food is cooked. They decline milk, but will eat butter, cheese and all varieties of sweets.

Perhaps it is on account of the vegetable diet and cornparatively small amount of meat they get to eat that they will eat high and putrid flesh when they have the chance so to do.

\section{Cultivation.}

In the dry season clearings are made by barking the trees to kill them, and not by cutting them down. Small holes are dug to obtain the soil for making the small mounds into the sides of which the yams and cassava roots are stuck, thus: This is done just before the rainy season sets in. The roots are dug up at the end of the rainy

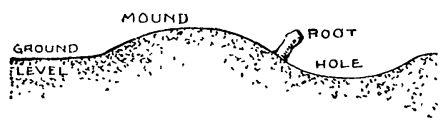


season. Cassava and yam plantations are generally placed near the villages, on both sides of the paths leading from one village to another; there are also paths round and through the cultivation patches.

\section{Fishing.}

The Ijos are the fishermen; they fish at the river mouths, and the fish and shrimps caught are dried in the sun until they stink. These people make their own nets either of stringy grass or of the mid rib of a palm (obtaining many strings from one) or European twine and rope. Fish are also speared at night, the fishing spears having loose points, or enclosures are made along the banks which are closed at high tide, the fish being taken out or speared at low water; this method is varied by pegging out a shallow at high tide, and fixing up mats wherein the fish get caught. At certain periods the mouths of the creeks are blucked and the fish stupefied with the juice of the cone of a plant, which does not affect the flesh; from one to a dozen cones, each about 3 inches long, are found on a single branch of the tree and when the cones are bruised they exude a yellow liquid which stupefies the fish. Shrimps and small fish are also caught in large open flatbottomed baskets, much as we catch lobsters and crabs in England; a bait is fixed inside and it is covered with a net having a small opening, the whole being sunk for 12 to 24 hours. Shrimps are also caught by the natives running along the

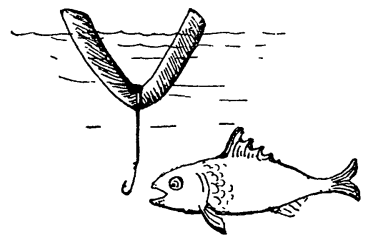

should be in the fish's mouth.) banks pushing an open basket in front of them which scrapes against the bank.

The Ijos also fish with a look attached to a piece of string about 1 foot long, which at the other end is attached to a bent float, so that when a fish gets hooked the bend is drawn down while the two ends bob up and down and show above the water that a fish is caught. (In the diagram the hook

\section{Hunting.}

The Sobos hunt the bush deer with dogs, spears, long Danes (flint-locks), traps, etc. ; for small deer, very often a hedge 1,000 yards long is set up between the bush and plantation with small openings about 20 feet apart, and behind the openings traps are set, the traps being springes. For large deer single traps like wire springes made of one or more flexible trees are set up on the path from the bush to the plantation; the game get caught by the neck.

\section{Habitations.}

Most Jekri towns are built on high land near water, not on a main river but on some winding creek, so that the town is hidden completely and can only be reached either from the creek or by means of a narrow bush path. The big chiefs have compounds of their own, generally oblong in form, the sides of the compounds being formed by rows of huts, or lyy one long hut divided into rooms, with entrance 
opening into the compound. The chief occupies one of these huts and his wives and slaves the rest. The entrance is at one end of the compound, and one has to enter either through the huts at that end or through a big doorway, the wall of which consists of posts bound together. At one end of the compound is the palaver house, with the side towards the court of the compound left wall-less, the roof being supported on posts. Sometimes the palaver house as well as the small juju-house is in the middle of the compound.

The houses are built of about eight tall posts, three on either side, and two taller ones in the centre at the gable ends to support the ridge pole; all the posts are forked at the top to support the side beams. The walls consist of thin sticks placed about 9 inches apart, strengthened by cross pieces all lashed in position by $t \overline{-}-t \bar{\imath}$-a thick stroug round native creeper-or by strips of so-called cane made by splitting the stems of the oil palm leaves. The spaces between the sticks are filled in with puddled clay. This is allowed to dry, and when cracks appear they are filled up with more clay and the drying allowed to go on again; cracks again filled up, and so on until the walls are consiclered perfect. Clay is found everywhere at various depths below the soil, and is therefore readily dug up. Some houses are washed over with a red clay which is lug up from the holes whence the building clay is obtained. The roofs of the houses are generally made of the leaves of a palm which grows at the mouths of the rivers whence they are brought up in canoes. The leaves (1) are first folded over (2) and then three tied together (3) with $t \bar{\imath}-t \bar{\imath}$, and laid in the sun until quite dry, when they form the thatch to be put on the roof.

The arrangements of the compounds are not always the same for the Jekris do not always live in compounds. For instance, in some towns the houses are built anyhow, while occasionally, although rarely, a long street runs right through the place. The Sobos and Ijos build their houses like those of the Jekris, but often the Ijos are nomads; the latter make the walls of their houses of mats. Sobo houses aregenerally inland, and the bush path opens into a broad main road at the
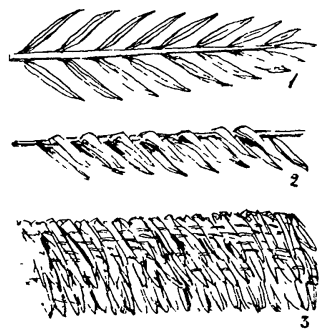
entrance of the town, contracting into a bush path again at the other end. Houses and compounds open on to this main road. At both ends of the town the houses have loopholes for watching arrivals. The diagrammatic plan of a Sobo town is given in the accompanying sketch. 
In the towns or villages of Jekri, Sobo or Ijo there are big excavations, close to the main road, from which the clay has been taken out; these holes get filled up with rubbish and dirt from the houses. Plantains and bananas are planted between the houses of all three tribes, and if any settlement is at all old, huge coco palıns are always found there.

The Jekris and Sobos and occasionally the Ijos raise the earth about 2 feet inside the house at one end or side, and on this embankment they place a mat or two for sleeping purposes; during the day it is used as a seat or table. The richer natives have tables like those of Europeans.

Some natives have truck beds made of long canes lashed together and raised on four forked sticks.

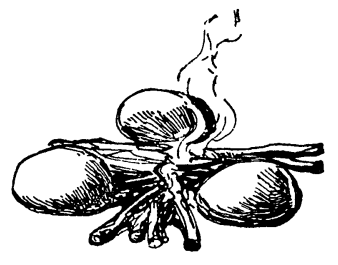

The cooking fires are made in huts close by, but in cold weather, or if the owner be rich, a fire is built in the middle of any house. Iron pots are used and very often native clay ones, which rest on three lumps of clay, the ground being hollowed out between the three lumps. Some natives dig a hole in which to make the fire.

Ijo houses are built on the main river bank and can be seen from the water; there is no order as regards their position and the towns are therefore built very irregularly.

\section{Dress.}

The Jekris do not twist or plait their hair. The men cut it shortish and the women dress theirs with a comb, smoothing it down by pulling a handkerchief half way down over it.

The men wear a cloth and singlet. The women wear a smaller cloth ( $\bar{a}$ lego $)$ tied round the hips with a handkerchief and then a larger cloth over it, covering them from over the breasts down to their feet ; this cloth is kept in position by tucking it in under the left arm. In no other tribes are the women so well covered as among the Jekris.

The Sobo women wear anklets of sections of elephant tusks, a short concave one on the right leg and a longer straight one on the left leg; such anklets weigh probably eight or nine pounds each.

\section{Skin marks.}

The skin markings consist of short straight ridges made with a sharp piece of hoop iron by successive operations. The skin is slightly cut and some soot (?) rubbed in; the wound is left to heal, and in doing so a very faint ridge remains. After a time this ridge is cut into and some more pigment put in, and the operation repeated until the ridge has been raised to the usual size. As the people grow old and the skin shrivels these ridges become more marked, unlike scars, which of course become less marked.

The Jekri men disfigure the skin occasionally, the women mark it generally. 
The Sobo men are generally without skin mutilations, but the women adorn almost any part of the body, having mostly a necklace of cicatrices and three cuts on the left temple. The Ijo men put the marks on any part of the body but not quite so much as their women do.

\section{Circumcision.}

All boys are circumcised in all three tribes, whether free or slave, and the operation is performed at any age, on babies a few weeks old, or on young fellows 15 or 16 years of age.

All Sobo women have their clitoris cut off; unless they have this done they are looked down upon, as slave women are who do not get cut; as soon, therefore, as a Sobo woman has collected enough money, she goes to an operating woman and pays her to do the cutting. The bleeding is sometimes very bad, and is stanched by a decoction male from leaves, bark, and sticks ground up. After the cure, the woman rubs a reddish-yellow colour over her body, from which it wears off in the course of a few days.

\section{Government.}

In all three tribes the head of a village is generally either an old man or a man who has the most worldly goods; there is no hard and fast rule. Amongst the Jekris he is generally the richest man; amongst the Sobos the oldest man; amongst the Ijos the headman must be an old man. The Jekris have a head chief for the whole tribe; but the richest man is the most looked up to. The Sobos have a king somewhere in the back country, but he cannot be of much account, as the King of Benin used to send down his men to any Sobo village and just take whom he liked, either freemen or slaves, for his yearly sacrifices. Even now some Sobos will not believe that the King of Benin has been smashed up. The Ijos are widely distributed over the Niger I)elta, fight a good deal among themselves, and are the hardiest of the three tribes.

The people are well treated by the chiefs, and chiefs will occasionally pay the fines imposed on a son when the father cannot help in order to save the family from disgrace.

\section{Slavery.}

Amongst the Jekris, if a slave run away, steal, or misbehave himself generally, one or both ears are cut off ; for adultery with a wife of a mastẹr he is killed, according to native law.

When the British Government established the Niger Coast Protectorate a proclamation was made that domestic slavery would be tolerated, but that slaves imported from other districts would be declared free. For a time it was not an uncommon sight at daybreak to see one or more slaves sitting round the Warri Consulate flagstaff awaiting freedom. Such men were freed if on investigation they made out their case, and they were allowed to go away or to remain in the Protectorate working for wages. 
To indicate that a slave is a bad individual, the Jekris cut a diagonal cross $x$ above each nipple on the breast; perpendicular or horizontal cuts indicate that the slave is not very troublesome.

Not many Jekris are free; generally it is only the chiefs and their families who are free, the rest of the people leing slaves. A chief can free a slave. Fathers who are hard up will sell, or rather pawn, a son for a puncheon of oil, say, the son is then, for the time being, a slave, but is redeemable. Similarly, a man or wuman can pawn him or herself, and on repayment of the loan become free again.

\section{Succession.}

Amongst the Jekris, if a man dies intestate, which means that before dying he has not called a meeting to say how his property is to be divided, it is apparently divided between his sons and daughters. The dead man's wives are taken by the sons, if young, as concubines, the elder women being kept about the place. If the man be rich, the women do nothing, if not, they must work. The Sobos and Ijos inherit property like the Jekris. Very often a rich man, before lying, decides that a certain son, no matter whether an elder or a younger son, shall inherit all his property, and in such case the daughters are taken care of by the favoured son as head of the house, and when married he then receives the "dash." Generally speaking, not the eldest son, but the son adjudged to have most sense, i.e., the fittest to succeed, is made heir. Descent is through the father.

\section{Palm Oil.}

The Sobos make the palm oil. They climb the palms by means of two kinds of slings placed round the trees: they rest the foot in the one, and in the other

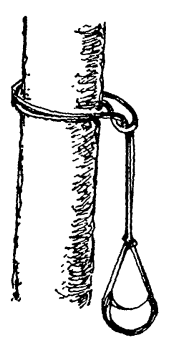
they place their hocks - they rest on one sling and raise the other with their hands, doing the reverse when coming down; the slings are made of strong $t \bar{\imath}-t \bar{\imath}$, twisted like manilla rope: they are very strong and stiff, and therefore easily moved when in use. The nuts grow in bunches between the leaves, black at first, but red when ripe. The bunches when cut are dropped down into the bush and left about in heaps till the nuts drop out; they are then collected and put into a V-shaped wooden trough placed on an incline with a small hole at the lower end. The troughs vary in size from 10 to 20 feet long, and from 2 to 3 feet deep. Water is poured over the nuts, which are allowed to soak or rot a little, then two, three, or four men (according to size of trough) stand in single file and jump on the nuts with their

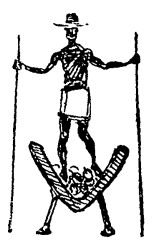
heels, the men sustaining themselves by means of sticks stuck into the ground on both sides of the trough, grasping a stick in each outstretched hand. As the oil gets pressed out of the outer shell of the nuts it floats on top of the water and is skimmed off, the water being run out through the hole, while fresh water is occasionally added. The nuts are then put into the sun, and when dry the 
women and children crack them with a piece of iron on a piece of hard wood, to get the kernel, and these in the trade are known as palm kernels.

The men, one or two, take their wives and children into the bush, build huts, make troughs, dig a well and work there as a family party ; in wandering through the bush one may come across several such parties. Palm oil nuts are carried on a stick across the shoulder, but, otherwise, heavy weights are carried on the head.

\section{Trade.}

The Sobos supply most of the palm oil and kernels and the bush deer. The Jekris buy most of the fish from the Ijos and are the great middlemen and traders.

In counting, the fingers and toes are used; the chiefs can count better than the mass of the people.

\section{Manufactures.}

The Sobos make fairly neat baskets, mats, etc., and also carve wooden figures ; some of the Ijos carve paddles. Neither Sobos, Jekris, nor Ijos appear to make cloth, but the Bini people do. Gourds are said to be hardened for use by soaking in water and the seeds shaken out when dry.

\section{Weapons.}

Sobos and Ijos have spears with iron heads. Spears were not seen amongst the Jekris, while the wounds dressed appeared to have been made by slashes with the macletas and were not spear thrusts.

\section{Pottery.}

Jekris, Sobos and Ijos make earthenware pots. They dig a hole in the ground and pick out a bluish sort of clay which they knead, and from which they throw out all hard pieces. The clay is worked up into rolls about 6 inches long and 1 inch in diameter. A shell or rounded piece of wood or of old pot is procured and the clay moulded on this, the sides of the coming pot being made by squeezing the clay with the thumb inside, and by superimposing several of the prepared rolls, while the whole is twiddled round with the left hand, the right hand doing the shapingfingers and a wet cloth are brought into use. The ornamentation consists of lines and dots but not of figures. The pots are put in the sun first for a short time to set, and are usually burnt, about six at a time, in a row;
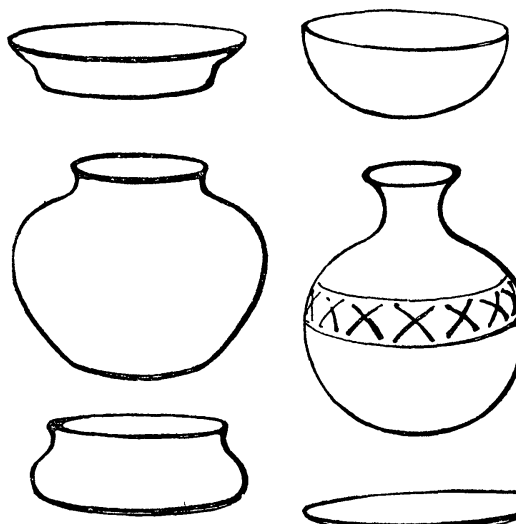

VARIOUS FORMS OF POTS MADE. 
good dry brushwood is laid over them crossways and set fire to; some of the pots crack from the irregular drying. There is always a lot of charcoal about from the previous firings, and this helps to retain the heat round the pots.

The soil at Warri consists of 3 to 12 inches of loam, below this to a depth of about 72 inches there is a sandy yellow clay more like sandstone, and below this depth the clay is found to be more putty-like in character. In this putty-like clay small white spots like chalk are met with, also red clay in small lumps, and a grey or blue clay in similar lumps; the pots are made of the blue clay.

Canoes.
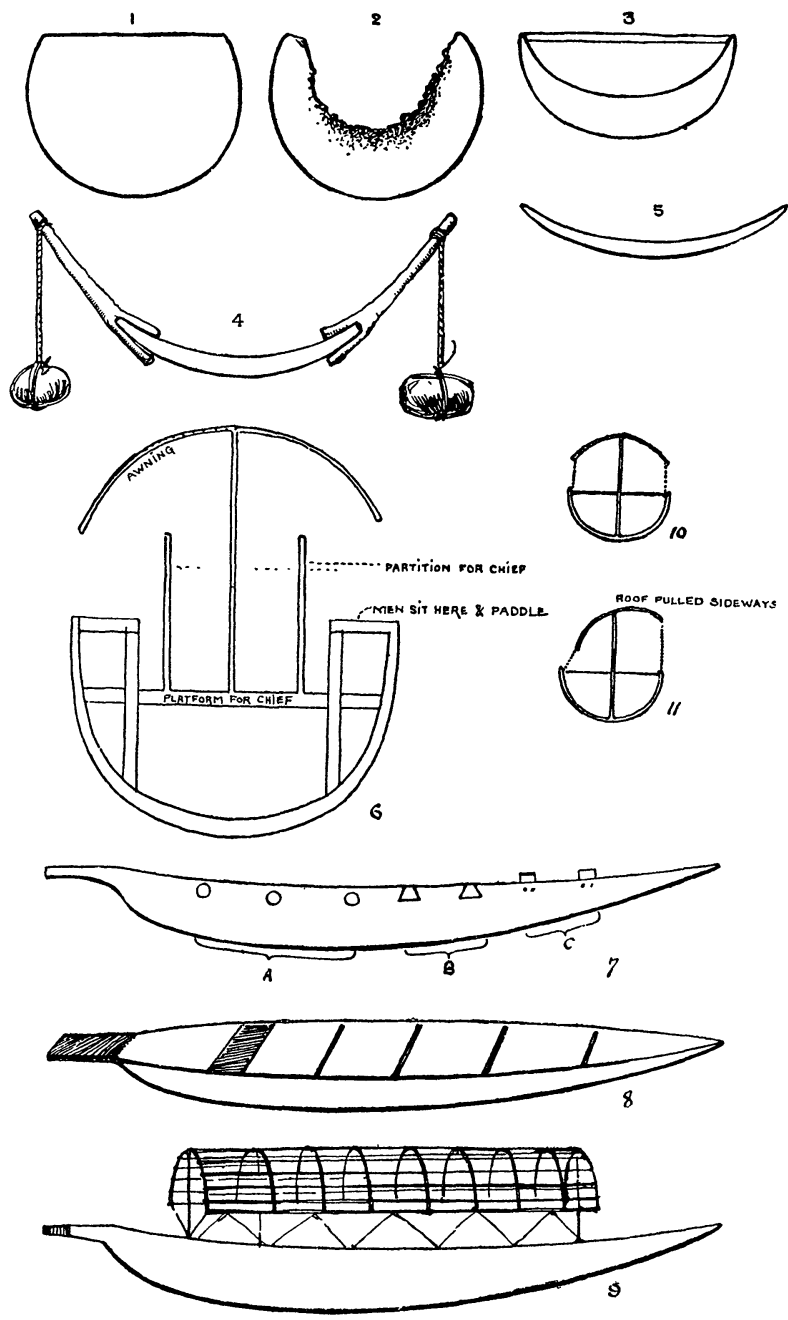

The Jekris do not make the large canoes (6); they are brought down from the interior. The smaller canoes are made of the trunk of a particular species of tree. When the tree is felled the trunk is trimmed for the outside shape of the canoe (1). A fire is then lighted on the uppermost flat side (2), the charred wood removed and a cross stay inserted (3) ; forked twigs are set with the fork on the sides and a weight at the other end so as to help weigh down the sides (4); this process is repeated until the canoe is thoroughly opened out (5). One end of the canoe is shaped into a fine 
bow, while the stern end is left flat, and on this the steersman stands (7, 8 and 9). Towards the stern end a broad seat is fixed, on this clay is plastered and on top of this again is placed the fire for cooking the food. The canoes are also provided with small flat sticks for the paddlers to sit on. These sticks are let into circular holes $(7 a)$, or put in wedge-shaped $(7 b)$, or laid on top of the bulwarks $(7 c)$, but in all three cases they were originally lashed into position by means of $t \bar{\imath}-t \bar{\imath}$; they are now secured by nails, when obtainable. Large canoes are provided with awnings $(9,10,11)$. A series of straight sticks are set up along the centre of the canoe and lashed to the seats. On top of these uprights a long semi-cylindrical framework is placed and the framework covered with mats. The framework can be tilted more or less to either side, and so kept in position by the yards with which it is furnished.

Whole families live in their canoes and travel up and down the river, but always wait for the tides and are never in a hurry to go anywhere. The chiefs have big canoes with plenty of small boys paddling; these they keep going for sometimes as much as twenty hours at a stretch. The boys often fall asleep and off their seats, and if they do not paddle properly a man hits them on the headthe boys being generally slaves.

\section{Diseases.}

In spite of their rubbing themselves with a strong smelling nut the natives are much bothered by mosquitoes and varieties of blow flies, but being naked they can generally feel when a noxious fly has settled on them and knock it off. However some flies deposit their eggs in the skin and cause much itching but not much sore. Chigoes, if allowed to remain, very often cause the tops of the toes to drop off. Worms small and long are met with, and the Guinea worms are probably introduced.

Malarial fever, dysentery, diarrhœa are common; so is "craw craw," eczema, and all the chest complaints; valvular disease of the heart, pointing historically to rheumatic fever, is not uncommon ; slight cases of leprosy exist, and ulcers of the leg are very common. There is a curious, but severe diseased state during which the skin and flesh wastes away, but it is curable. A troublesome complaint, because there appears to be no cure for it, is this: the skin splits round the base of the toe and hardens gradually to such an extent that the circulation is stopped and the toe withers away.

The form of smallpox which affects the natives more or less severely is not found to communicate itself to Europeans.

Epilepsy and hysteria are met with. There is very little ophthalmia.

Toothache is only caused by deterioration due to enamel being knocked off by a blow; the jaws being large and the teeth wide apart, nothing gets fixed between them. The teeth even of middle-aged people are well worn down by the gritty nature of their food.

Albinism is found in all the tribes, but no polydactylism, steatopygea, cleft palates nor hare-lips were observed. Idiots exist, but no special attention is paid to them. There is occasional baldness in old people. Club foot has been seen. 


\section{Sanitary Matters.}

The Sobos are the cleanest in their towns, but do not keep themselves personally clean except on juju and state days; they also wear little clothing. The Ijos are always washing themselves, and as one passes through their towns the women are seen doing the hair of men or of other women. The Jekris are not very clean in their towns, but keep themselves personally cleaner than the two other tribes; being miłldlemen they are generally wealthier and consequently dress much better. All three tribes oil themselves.

In consequence of the poor nourishing quality of their food the people have to eat more than Europeans do, and consequently they defecate more frequently. As regards sanitary arrangements nearly all villages are on the water-side so that defecation takes place direct into the water. The Ijos have long poles jutting out over the water supported on forked uprights for use as closets. One Sobo village was noticed where by common consent a portion of the bush appeared to have been allotted as cloaca. The smell of urine only occasionally makes itself felt about a village.

The Jekris make refuse heaps of waste food, etc.

The Jekris rinse out the mouth and rub the teeth with the fingers after eating; all tribes are to be seen with the "chew stick," a fibrous stick about half an inch in diameter, which is skinned, chewed and spat out, an operation which is performed every morning to keep the teeth clean.

As the native uses his left hand to clean himself after defecation he eats with his right hand, shakes hands with his right hand and offers things with his right hand-the right hand being the clean hand.

\section{Pathology.}

If a native man (or woman) is suffering froin a pain or swelling he nearly always makes incisions on the skin over the affected part something similar to European cupping.

A wound is allowed to heal from the bottom up, as the natives have no idea of sewing it up. Generally they make messes of chewed leaves, the pulp from some trees, cow dung, etc., which mixture they put into the wound; the mixture is left there until it stinks too much, when a fresh mess is put on.

With broken arms and legs they use, when possible, rough splints, but no trouble is taken to ascertain whether the limb is properly set, nor is any means taken to keep the limb at rest.

The Jekris believe in the Ijo doctors and go to them for treatment. When native methods fail the natives come to European doctors as a last resource.

A peacock's feather is stuck over the house of a person who is ill.

\section{Salutations (Jekri).}

When handshaking as they withdraw hands they click with the fingers on to the ball of the thumb. 
If an inferior meet a superior the former goes down on his left knee, slaps his leg above the knee, holds out his hand, which his superior grasps, the superior at the same time raising him up. As they withdraw hands they click.

A chief never allows a native below him in rank to have the latter's umbrella open before him (the chief), so an inferior closes his unbrella on approaching a chief, while the chief keeps his umbrella open.

In begging they rub the flat palms of the hands together much as Europeans hold their hands when praying.

If displeased, as in a court case, they close the fin-
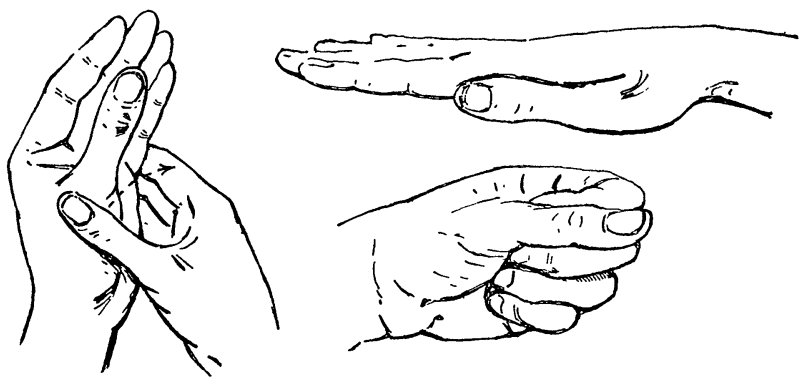
gers of the left hand to a cone, and with the thumb of the right hand pressed over the ball of the thumb of the left hand they click the right hand thumb on to the inside of the left hand.

If pleased, they slap with the right hand on to the closed fist of the left hand; when many do this at the same time it sounds like a lot of nuts being cracked.

\section{Games (Jekri).}

The children have miniature bows and arrows.

Boys have a game very much like peg top. There is a long thin convolute shell which they spin from the point with the fingers of one hand into a small hole about, 1 inch deep and about $2 \frac{1}{2}$ inches in diameter. The other boys then come and spin other shells into this one, so driving it away and leaving theirs to spin in its place. Boys also play at shooting, being at a distance of 5 yards, one boy being placed at each end of the shoot.

A woman's game is to choose a bare piece of sandy ground in which an armlet is hidden and the sand smoothed over the surface. The armlet is to be found by others, who with one or two bent fingers dray across the sand in hopes of finding the article.

In wrestling, they grip each other at the back of the neck with one hand and then with the other try to grip under the opponent's arm and close, throwing the opponent on to his back. There is no throwing the opponent over the shouller, etc. Before the match they grease themselves well.

\section{Expression of Colour (Jekri).}

Black, $d u d u$; white, fufé; red, cludé, practically anything not white nor black; yellow is not recognized as a colour ; green, égo (accent on the o), often it is spoken 
of as $d u d u$. The word égo is not used by itself, thus to say eğ (tree) égo (green), a green tree would not be understood; one must say eğ to mu égo, literally, " tree which catch green." Paint is known by the name applied to tar, $\breve{d} d a$. To say "green paint," they say $\breve{d d a}$ to mu égo, tar which catch green, but for red paint they say $\breve{\partial} d a d \check{d} d \dot{e}$, tar red.

\section{Mensuration (Jekri).}

'The majority of natives count up to ten on fingers and toes, and probably not one per cent. can count up to two hundred. In some respects the names of the numerals are both peculiar and complicated. Thus, for 71, they say okalogwad orui $=$ one past 10 in front of 80 , and for 76 they say mayonétcheto orui=four not reaching to 80 .

\section{Language (Jekri).}

We have seen above that there are many Portuguese words still in use by the natives; they also adopt English words such as ujeli=goal, bøtor=button, etc.

Some words have to serve reciprocal purposes such as $k o$, to teach or to learn; $f e$, to look for, and to find.

In many cases the one word has to serve for two meanings, as fo, to jump or to fly ; igve, to wash or to swim.

Often one word appears to have two meanings, but it is pronounced slightly differently according to what is meant, thus: ugugu (dental)=ghost; ugugu (labial) $=$ crocodile.

There are a large amount of compound nouns such as onietomur $\iota=$ carrier, lit. onie, person ; to, who ; $m u$, carries ; ur $u$, things ; $p e j a=$ to fish from ; eja, fish ; $p a$, to kill.

The pronoun is inflected and not the verb, thus: mo ri, I see; ma ri, I shall see; $m$-oku ri, I have seen.

\begin{tabular}{|c|c|c|c|c|}
\hline \multicolumn{3}{|r|}{ The pronouns. } & With Verb. & As Negative. \\
\hline \multicolumn{3}{|c|}{1 person singular-m $m, m o, \breve{e} m \breve{\imath}$} & mo & $m e^{1}$ \\
\hline 2 & , & $, \quad \bar{u} r, u \cdot r, r e ́$ & $w o$ & $u e^{\prime}$ \\
\hline 3 & ” & $" \quad$ on, o, ro & 0 & $\dot{e}$ \\
\hline 1 & ” & plural-ené $\quad \ldots$ & cné & cné \\
\hline 2 & , & $" \quad \bar{u} r, w o, r \dot{e}$ & 100 & wé \\
\hline$\hat{\jmath}$ & ” & anga $\quad \ldots$ & anga & angé \\
\hline
\end{tabular}

'é =ay, thus : mé is pronounced may. 
Language.

Gi. Verb Active to say.

\begin{tabular}{|c|c|c|c|c|}
\hline Indicative. & Present. & Past. & Future. & Negative for all three tenses. \\
\hline Singular 1 & mo gi & molka gi & ma gi & $m e ́ s i$ \\
\hline ” 2 & wo gi & woka gi & wa gi & wé gi do not say; have not \\
\hline ” 3 & $o g i$ & oka gi & $a g i$ & said ; will not say. \\
\hline Plural 1 & ené gi & enoka gi & enar gi & ené gi. \\
\hline$" 2$ & wo gi & woka gi & $w a g i$ & vvé yi. \\
\hline$" 3$ & anga $g i$ & angoka $y i$ & angur gi & angé gi. \\
\hline Imperative . & $g i$ say & .. & $\ldots$ & magi-do not say. \\
\hline
\end{tabular}

The ordinary Jekri greeting is wo wunora, lit. you live, i.e., you are well. To a stranger they say oluka wa, friend, come! To ask "Who is that?" they say uor nisi, lit. you who.

The verb shé appears to be a sort of auxiliary, it means make, do, be, thus: anenon shé ré (uor), lit. sorrow does you, meaning you are sorry.

There is practically no interrogative; "Do you see?" is expressed by wo ri lit. you see; and to be emphatic they will say uor, wo ri, lit. you! you see! meaning hi! you! do you see?

\section{Canoe Boy's Songs.}

1. Onéyé owo mo ré ra shé oluka Oné to ré owo. Té Onéyé trade I go buy do friend Onéyé who went trade. You gibé mi Onéyé té gibonon Onéyé. Owo mo ré ra not tell me Onéyé you did not tell me Onéyé. Trade I go buy shé do ohouvo.

do goodbye trade.

The meaning of which is that a woman has gone to trade without telling her friend that she was going, i.e., she played her false.

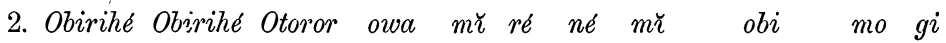
— — - father my go send me up country I said ma ré obi Otoror owa $m \check{\imath}$ ré né $m \check{\imath}$ obi not I (want) go up country — father my go send me up country. Sobo Quon o lu bé mǔ éju é éyé Ogbi ausén Obirihé. han hit (to ?) me eye —_ - - 


\section{Explanation of Plates VI to $X$.}

\section{Plate VI.}

Figs. 1 \& 2.-Jekri paddles, probably made by Ijos.

Figs. 3 to 8.-Handles and staves of paddles.

$$
\text { Plate VII. }
$$

Figs. 1, 3, 4, 5. - Incised calabashes.

Fig. 2.--Poker-work calabash.

Fig. 6.-Fly whisk (from Benin ?).

Fig. 7.-Bell shaped iron rattle.

Fig. 8. - Kruboy flute.

Fig. 9.-Silver bracelet made by Jekris.

\section{Plate VIII.}

Fig. 1.-Jekri canoe head-piece.

Fig. 2.-Juju worn by Sobos on head (at dances?).

Fig. 3.-Juju worn by Jekris on head (at dances?).

Figs. 4, 5, 6.-Jekri drums.

Fig. 1.-Ijo juju.

\section{Plate IX.}

Figs. 2, 3, 4.-Jekri wooden combs probably made by Ijos. Figs. 5, 6, 7.-Sobo wooden combs, probably made by Ijos. Fig. 8.-Wicker comb, Jekri.

\section{Plate $X$.}

Fig. 1.-Benin rattle; some of the victims were said to have been stunned with this implement.

Fig. 2.-Warri fetish.

Fig. 3.-Yoruba knife.

Fig. 4.-Kruboy harp with calabash sounding board.

Fig. 5.- - Silver ring made by Jekris.

Fig. 6. -Jekri fetish, made by Sobos.

Figs. 7, 8.-Calabash with poker-work pattern. 


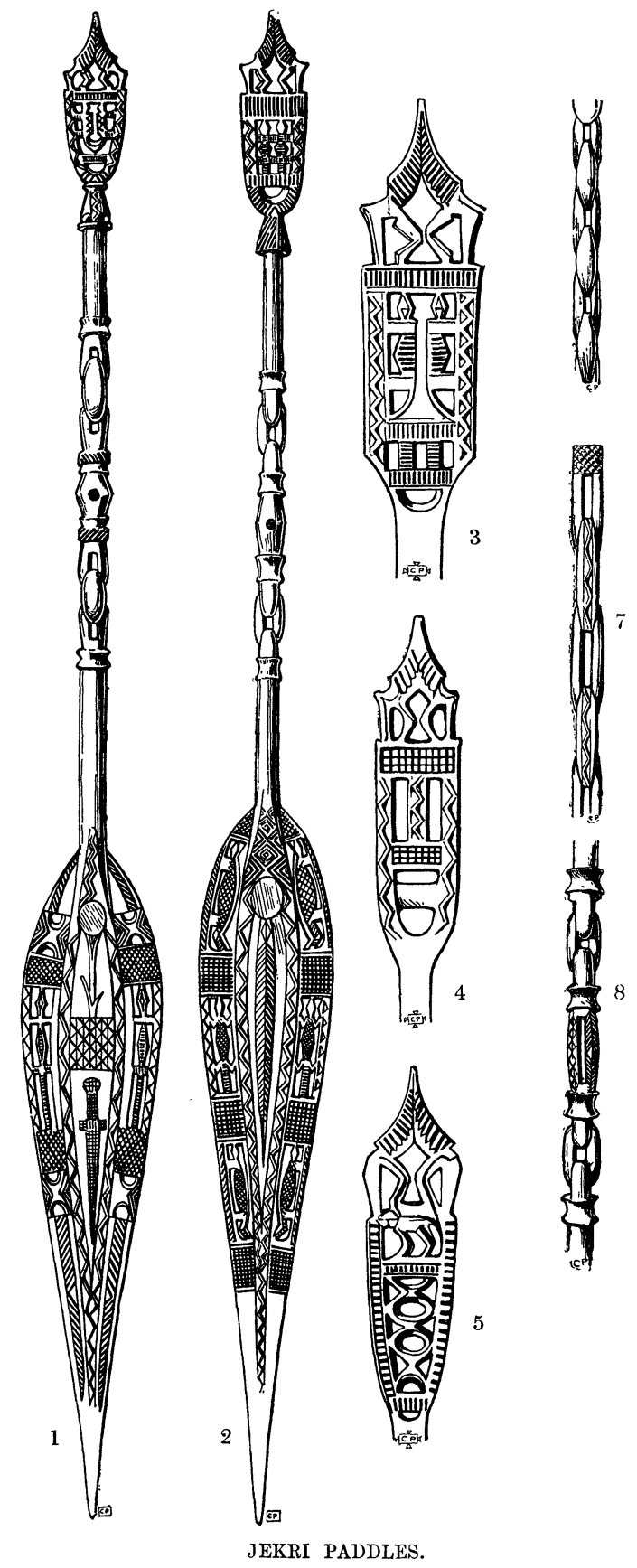




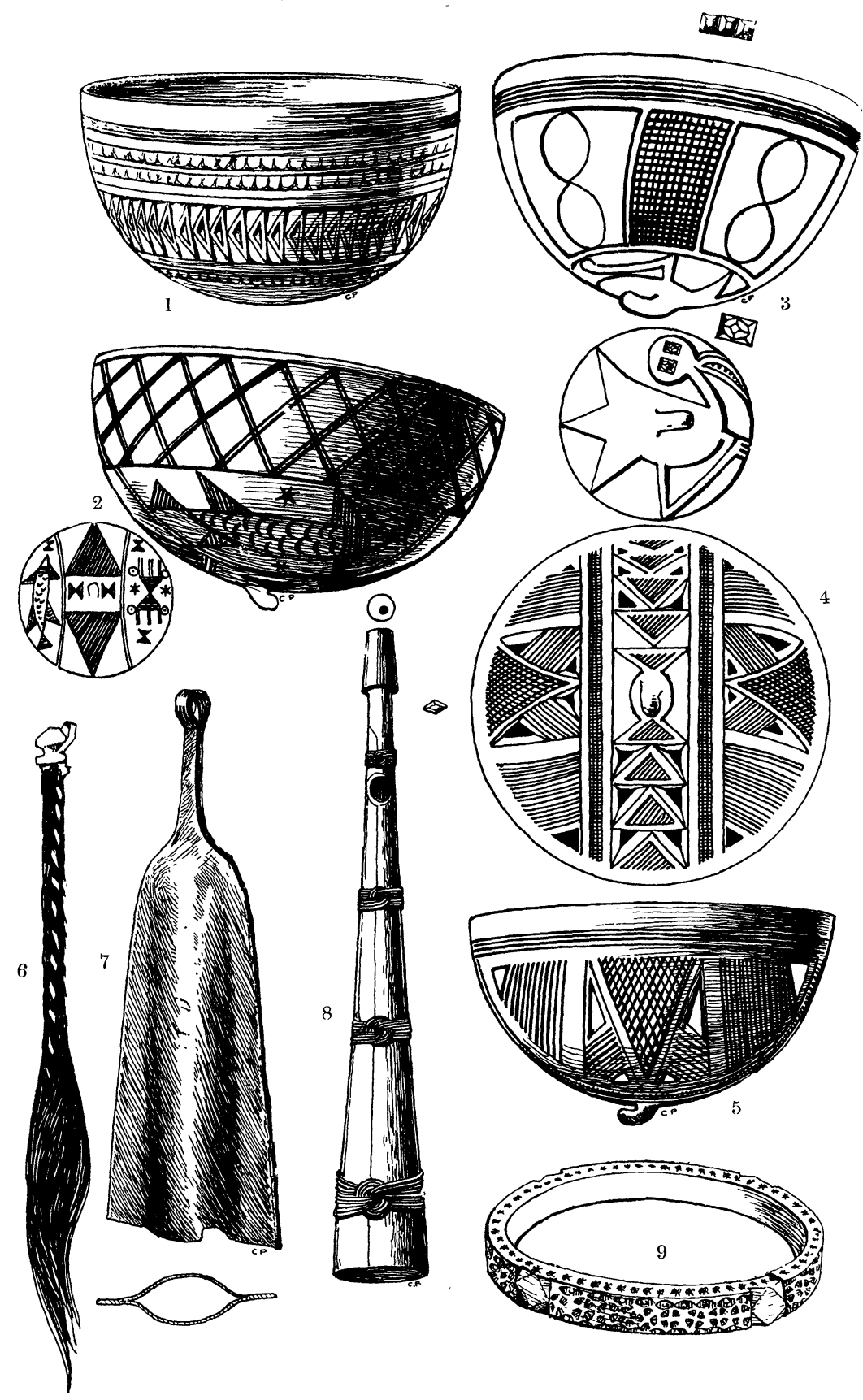

CALABASHES, ETC'., FROM WEST AFRIC'A. 


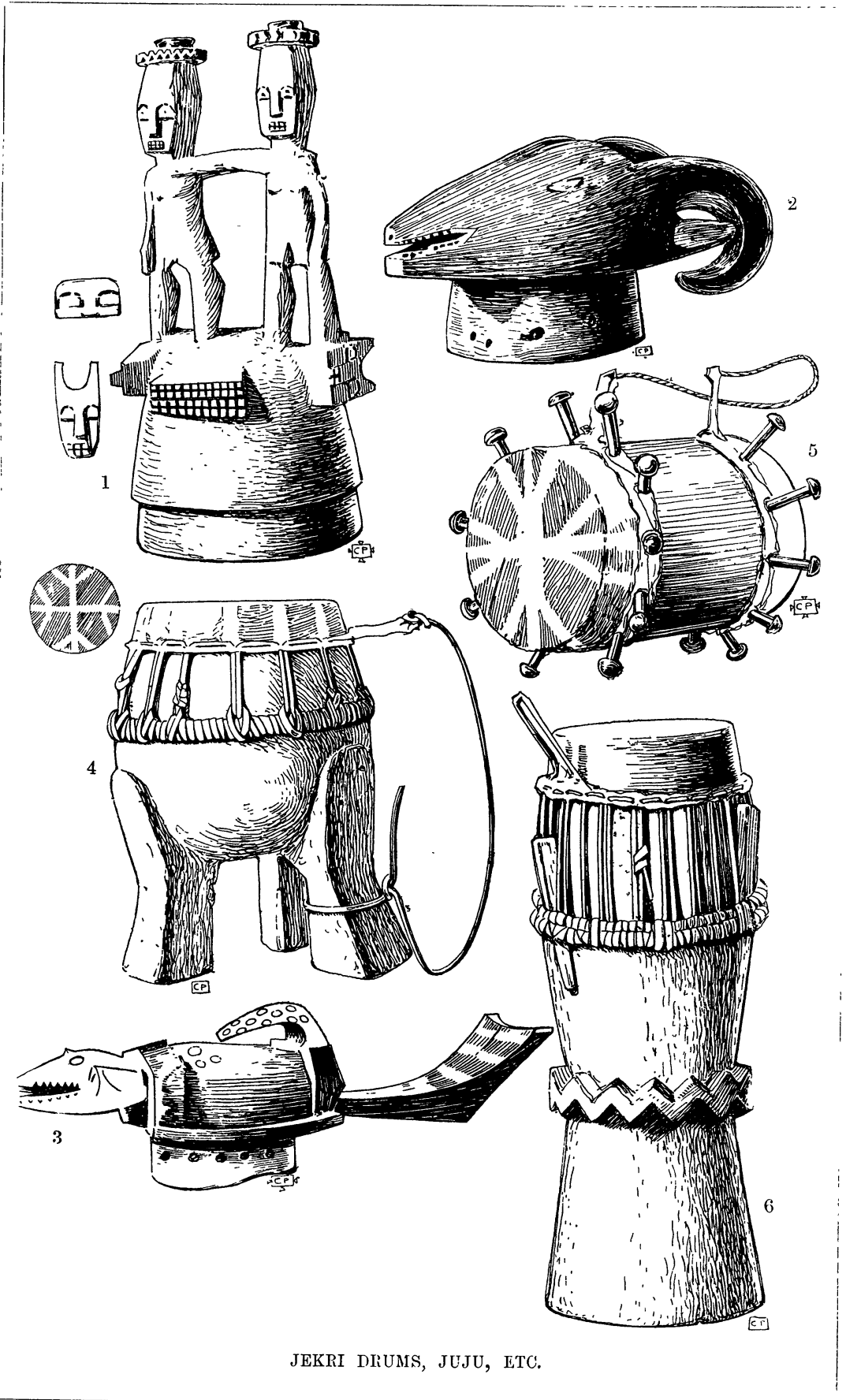




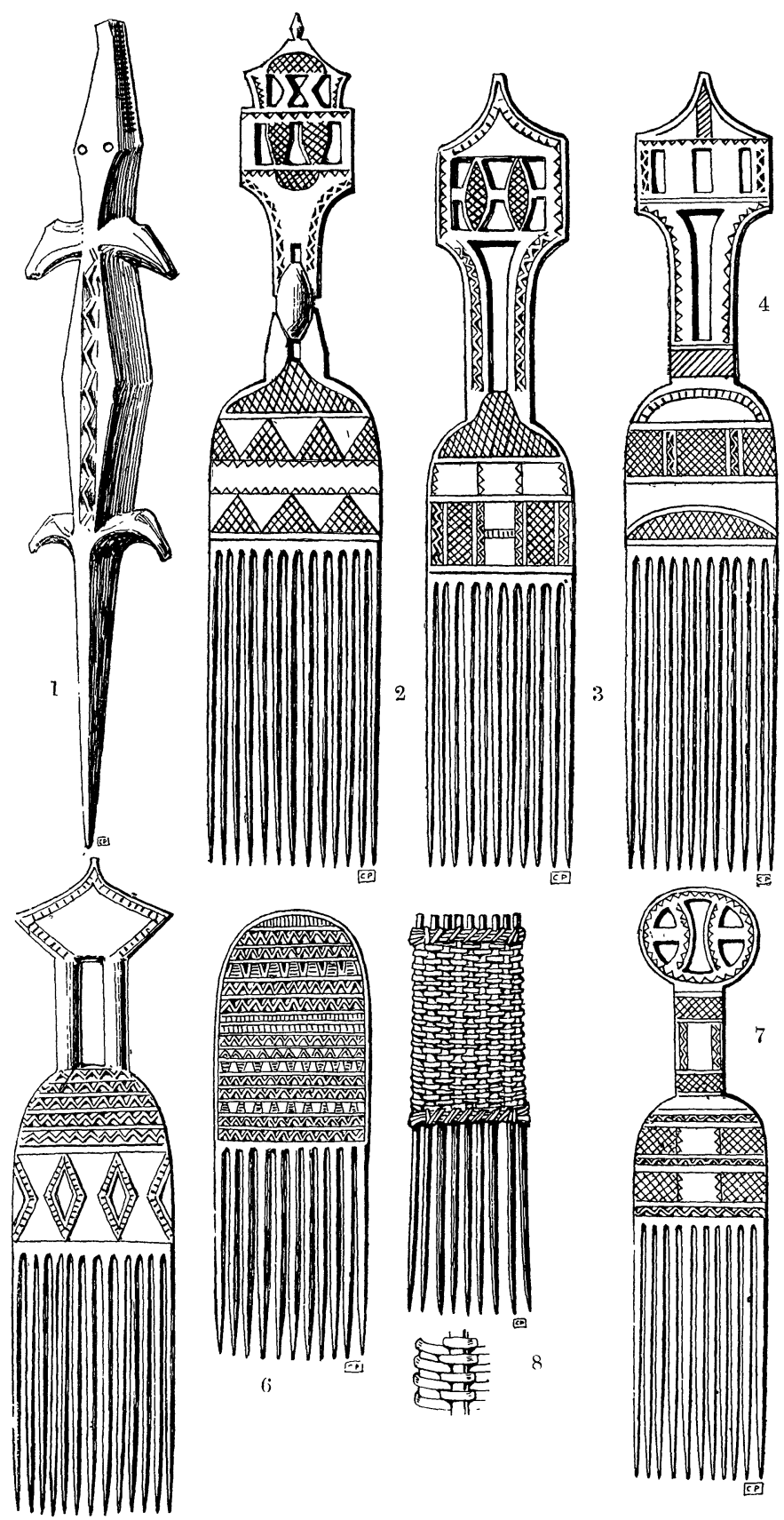

IJ() IUU ANI) JEKRI COMUS. 




